\title{
Weight-length relationships of six shrimp species caught off the Madeira Archipelago, Northeastern Atlantic
}

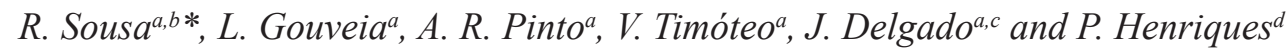 \\ a'Direção de Serviços de Investigação - DSI, Direção Regional das Pescas - DRP-RAM, \\ Estrada da Pontinha, CP 9004-562, Funchal, Madeira, Portugal

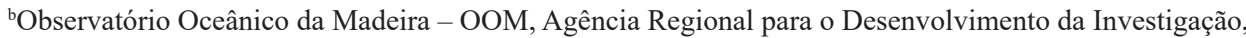 \\ Tecnologia e Inovação - ARDITI, Edifício Madeira Tecnopolo, Piso 0, CP 9020-105, Funchal, Madeira, Portugal \\ ${ }^{\mathrm{c}}$ Centro Interdisciplinar de Investigação Marinha e Ambiental - CIIMAR, \\ Rua dos Bragas, 289, CP 4050-123, Porto, Portugal \\ dUniversidade da Madeira - UMa, Campus da Penteada, CP 9000-390, Funchal, Madeira, Portugal \\ *e-mail: ricardo.sousa@oom.arditi.pt
}

Received: May 30, 2017 - Accepted: August 14, 2017 - Distributed: February 28, 2019

(With 1 figure)

\begin{abstract}
Length and weight relationships and descriptive statistics are reported for six shrimp species caught off the Madeira archipelago between 1983 and 2014 using bottom and floating traps from depths ranging from 50 to 1,300 m. The parameter b ranged between 2.36 for Plesionika ensis and 2.97 for Plesionika williamsi. All species showed a pattern of negative allometric growth. To the authors' knowledge all weight-length relationships presented herein are recorded for the first time from the Madeira area, and in the cases of Ligur ensiferus and Plesionika ensis are the first references worldwide.
\end{abstract}

Keywords: carapace length, negative allometric growth, weight-length relationships, shrimps, Madeira archipelago.

\section{Relações peso-comprimento de seis espécies de camarão capturados ao largo do arquipélago da Madeira, Atlântico Nordeste}

\section{Resumo}

As relações peso-comprimento e a estatística descritiva foram estimadas para seis espécies de camarões, capturados ao largo do arquipélago da Madeira, entre 1983 e 2014, usando armadilhas de fundo e alvoradas entre os 50 e 1.300 metros de profundidade. O parâmetro b variou entre 2,36 para Plesionika ensis e 2,97 para Plesionika williamsi. Todas as espécies evidenciaram um padrão de crescimento alométrico negativo. De acordo com o conhecimento dos autores, todas as relações peso-comprimento são aqui apresentadas pela primeira vez para a área da Madeira e no caso de Ligur ensiferus e Plesionika ensis são a primeira referência mundial.

Palavras-chave: comprimento do cefalotórax, crescimento alométrico negativo, relações peso-comprimento, camarões, arquipélago da Madeira.

\section{Introduction}

In fisheries research, weight-length relationships (WLRs) allow the estimation of the average weight at a given length in a specific geographic area (Ferreira et al., 2008). The WLRs are widely presented as a useful tool with wide application in several domains of the fishery science. WLR's are used in the comparison of life history between-regions, population dynamics, ecology, stock assessment, management and to estimate the production and biomass of a given population (Anderson and Gutreuter, 1983; Erzini, 1994; King, 1995; Santos et al., 2002). Also, the condition factor is often used to quantify an animal's physical wellbeing and thought to be a useful complement to growth estimates of crustaceans (Bagenal and Tesch, 1978; Rochet, 2000).

Decapod crustaceans have been studied during several scientific surveys carried out in the Madeira archipelago since the early eighties. Those prospective surveys were aimed at determining the fisheries' potential of non-exploited resources and diversifying the commercial fisheries, thus reducing the fishing pressure on the heavily fished coastal areas (Biscoito, 1993; Biscoito et al., 1992).

Several species of shrimps are known to occur along the insular shelves and slopes off Madeira archipelago (Biscoito, 1993). Regardless of its economic and ecological importance and fishery potential, very few 
documented studies are available on WLRs, biology, population dynamics and condition factor of the shrimp species in this area. The few studies have focused on the biology of Heterocarpus ensifer Spence Bate, 1888 (Pérez-Peñalvo et al., 2009), Plesionika narval (Fabricius, 1787) (Sousa et al., 2014) and Plesionika edwardsii (Brandt, 1851) (González et al., 2016) in this region.

The aim of this work is to study the weight-length relationship and condition factor of six species of shrimps caught in Northeastern Atlantic, archipelago of Madeira, with the goal to provide guidelines for current fisheries workers dealing with length-weight data of these species. It is the first approach to WLRs of these species in this area of the Atlantic, and the WLRs for Ligur ensiferus (Risso, 1816) and Plesionika ensis (A. Milne-Edwards, 1881) are provided for the first time.

\section{Material and Methods}

The specimens examined in this study were obtained from a series of research surveys of the epi and benthic fauna carried out on the insular shelves and slopes off the Madeira archipelago, Northeastern Atlantic (Figure 1), between 1983 and 2014. The depth of the surveys ranged from 50 to $1.300 \mathrm{~m}$, using bottom and floating traps as fishing gear. All individual shrimps were sampled. The carapace length $(\mathrm{CL})$ was measured to the nearest $0.01 \mathrm{~mm}$ from the posterior margin of the orbit to the posterior dorsal margin of the carapace using electronic digital calipers. The individual weight (W) was recorded using an electronic digital scale, with an accuracy of $0.01 \mathrm{~g}$. Sex was determined by the presence or absence of masculine appendages in the second pair of pleopods, through observation under a stereoscopic microscope (Zariquiey-Alvarez, 1968).

A more detailed description of the survey's design, fishing and sampling methodologies is available in Biscoito et al. (1992) and Sousa et al. (2016).

The weight length relationship was estimated for combined sexes, females and males, using the equation $\mathrm{W}=\mathrm{aL}^{\mathrm{b}}$ (Bagenal and Tesch, 1978), where $\mathrm{W}$ is the total weight in grams, $L$ the carapace length in milimetres, $a$ is the intercept (condition factor) and $b$ is the slope (relative growth rate). The parameters $a$ and $b$ were calculated by linear regression analysis fitted by the least-squares method over $\log$-transformed data $(\log \mathrm{W}=\log \mathrm{a}+\mathrm{b} \log \mathrm{L})$ afterward the use of log-log plots to detect and exclude outliers (Froese, 2006).

The coefficient of determination $\mathrm{r}^{2}$ was used as an indicator of the quality of the linear regression (King, 1995) and the nature of growth was tested using Student's t-test in order to determine if the $b$ coefficient was different from 3 with a significance level of 0.05 (Zar, 1996). The occurrence of significant differences in the relative growth rate between sexes was tested using Student's t-test.

\section{Results}

A total of 1,557 shrimps of 6 species belonging to the families Acanthephyridae: Acanthephyra eximia Smith, 1884; Hippolytidae: L. ensiferus and Pandalidae: Heterocarpus laevigatus Spence Bate, 1888; P. ensis; Plesionika martia (A. Milne-Edwards, 1883) and Plesionika williamsi Forest, 1964, were sampled from depths ranging from 50 to $1,300 \mathrm{~m}$.

The species with the smallest mean carapace length was P. ensis $(19.24 \pm 3.36 \mathrm{~mm})$ and the largest H. laevigatus

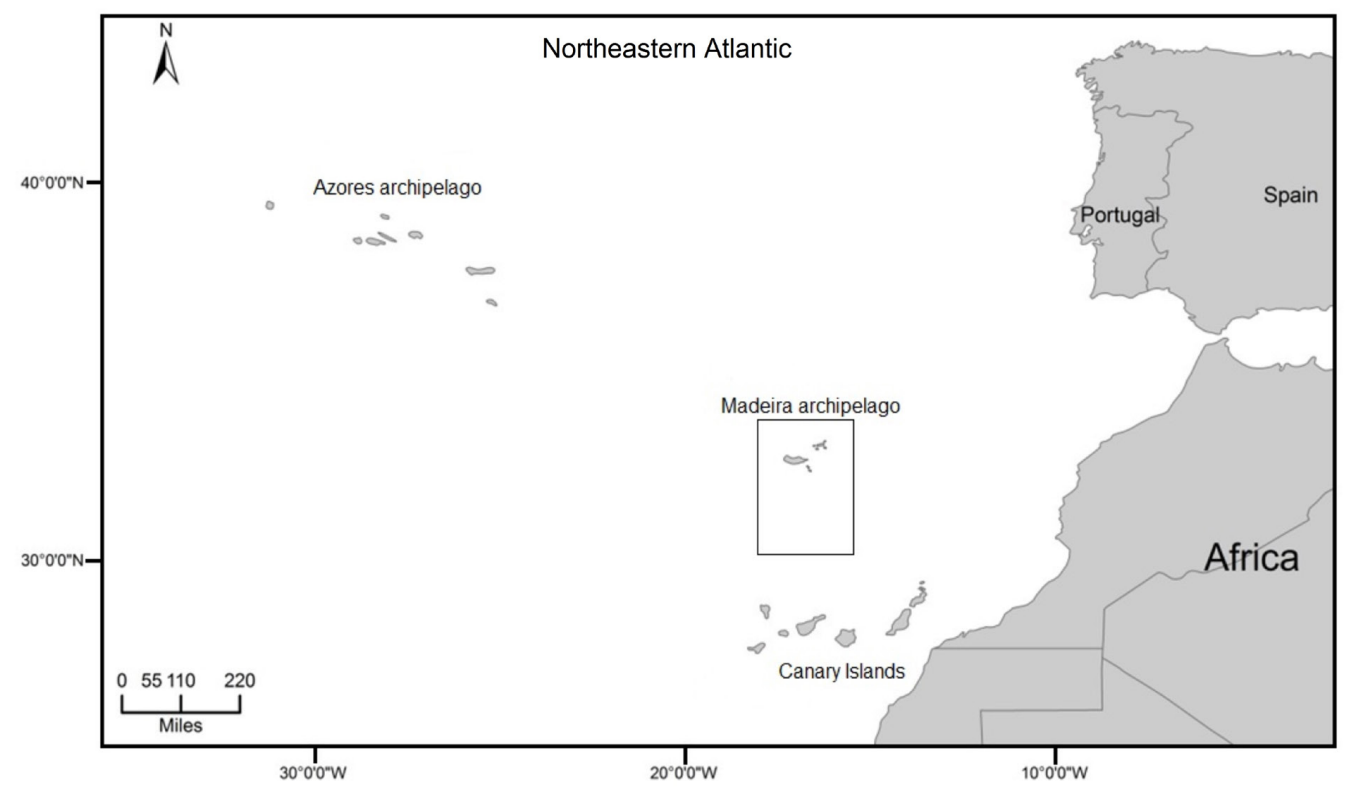

Figure 1. Geographic location of the study area, Madeira archipelago, Northeastern Atlantic. 
with a mean carapace length of $44.30 \pm 6.16 \mathrm{~mm}$ (Table 1). In terms of body weight, the lightest species was $P$. ensis with a mean weight of $5.23 \pm 2.49 \mathrm{~g}$ and the heaviest $H$. laevigatus (35.30 $\pm 13.34 \mathrm{~g})$.

The WLRs, related statistics and nature of growth for six shrimp species are presented in Table 2. The estimated relative growth rate ranged between 2.36 for $P$. ensis (males) and 2.97 for $P$. williamsi (combined sexes).

The relative growth pattern was similar between females and males for all six species revealing negative allometric growth in both sexes. The slopes of the regression were tested between sexes and showed that for A. eximia, L. ensiferus, $P$. martia and $P$. williamsi there were no statistically significant differences. However, for $P$. ensis the results of the Student's t-test showed that $\mathrm{b}$ was significantly different between sexes $(\mathrm{T}=3.40, \mathrm{p}<0.05)$. The parameter $\mathrm{b}$ was also significantly different for $H$. laevigatus $(\mathrm{T}=4.00, \mathrm{p}<0.05)$. Nonetheless the pattern of relative growth for both sexes in $P$. ensis and H. laevigatus was negative allometric with b varying between 2.36 for males and 2.72 for females of P. ensis and between 2.61 for females and 2.88 for males of H. laevigatus.

\section{Discussion}

The size ranges presented herein are in accordance to those studied so far in other areas. For all species, females achieved larger sizes than males. This may result of differential morphological development, reproductive investment and distinct habitat preference (King, 1995).
The estimated parameter $b$ showed negative allometric growth for all species and are supported by high values of correlation indicating an elevated predictability between carapace length and weight of the studied shrimps. These results fall within the expected range of values for this parameter for most aquatic organisms, which lies between 2.5 and 3.5 (Carlander, 1969; Froese, 2006), values of $\mathrm{b}<2.5$ or $>3.5$ are mostly caused by samples with narrow size ranges as demonstrated by Carlander (1977).

The WLR is a practical condition index and may vary temporally according to factors such as food availability, feeding rate and reproductive activity, however the $b$ parameter usually does not vary significantly throughout the year (Bagenal and Tesch, 1978), and together with a (condition factor) can be considered mean annual values, as suggested by several authors (Santos et al., 2002; Andreu-Soler et al., 2006). The results indicate a strong pattern of negative allometric growth in the studied species of nektobenthic shrimps off the coast of Madeira which is in accordance with previous studies for pandalid shrimps $P$. edwardsii, Plesionika antigai Zariquiey Álvarez, 1955, Plesionika gigliolii (Senna, 1902), P. narval, Plesionika heterocarpus (A. Costa, 1871) and P. martia (Martins and Hargreaves, 1991; González et al., 1997, 2016; Company and Sardà, 2000; Maiorano et al., 2002; Thessalou-Legaki et al., 2005; Vafidis et al., 2008; Sousa et al., 2014). The same pattern is also well known for Aristaemorpha foliacea (Risso, 1827) (Ragonese et al., 1997),

Table 1. Descriptive statistics for 6 shrimp species, Madeira archipelago, northeastern Atlantic.

\begin{tabular}{|c|c|c|c|c|c|c|c|}
\hline \multirow{2}{*}{ Family / species } & \multirow{2}{*}{ Sex } & \multirow{2}{*}{$\mathbf{n}$} & \multicolumn{5}{|c|}{ Carapace length $(\mathrm{mm})$} \\
\hline & & & Mean & S.D. & Min & Max & $\mathbf{C V}$ \\
\hline \multicolumn{8}{|l|}{ Acanthephyridae } \\
\hline \multirow[t]{3}{*}{ Acanthephyra eximia } & $\mathrm{F}+\mathrm{M}+\mathrm{I}$ & 388 & 23.32 & 5.29 & 12.69 & 39.75 & 22.69 \\
\hline & $\mathrm{F}$ & 249 & 23.44 & 5.43 & 12.69 & 39.75 & 23.44 \\
\hline & M & 120 & 23.12 & 5.18 & 15.02 & 39.67 & 22.41 \\
\hline \multicolumn{8}{|l|}{ Hippolytidae } \\
\hline \multirow[t]{3}{*}{ Ligur ensiferus } & $\mathrm{F}+\mathrm{M}+\mathrm{I}$ & 139 & 19.25 & 3.09 & 11.03 & 26.30 & 16.05 \\
\hline & $\mathrm{F}$ & 72 & 19.54 & 3.21 & 11.03 & 26.30 & 16.44 \\
\hline & M & 19 & 18.74 & 2.30 & 13.00 & 22.39 & 12.24 \\
\hline \multicolumn{8}{|l|}{ Pandalidae } \\
\hline \multirow[t]{3}{*}{ Heterocarpus laevigatus } & $\mathrm{F}+\mathrm{M}+\mathrm{I}$ & 221 & 44.30 & 6.16 & 26.61 & 59.09 & 13.90 \\
\hline & $\mathrm{F}$ & 143 & 46.61 & 5.50 & 32.96 & 59.09 & 11.80 \\
\hline & M & 74 & 39.84 & 4.65 & 26.61 & 49.22 & 11.68 \\
\hline \multirow[t]{3}{*}{ Plesionika ensis } & $\mathrm{F}+\mathrm{M}+\mathrm{I}$ & 81 & 19.24 & 3.36 & 12.00 & 26.30 & 17.48 \\
\hline & $\mathrm{F}$ & 40 & 20.06 & 3.26 & 13.00 & 26.30 & 16.23 \\
\hline & M & 15 & 18.73 & 2.32 & 13.00 & 22.39 & 12.38 \\
\hline \multirow[t]{3}{*}{ Plesionika martia } & $\mathrm{F}+\mathrm{M}+\mathrm{I}$ & 51 & 20.08 & 2.35 & 14.00 & 26.23 & 11.70 \\
\hline & $\mathrm{F}$ & 24 & 20.95 & 2.21 & 17.42 & 26.23 & 10.57 \\
\hline & M & 22 & 19.66 & 2.00 & 16.01 & 23.76 & 11.15 \\
\hline \multirow[t]{3}{*}{ Plesionika williamsi } & $\mathrm{F}+\mathrm{M}+\mathrm{I}$ & 677 & 26.48 & 3.87 & 15.63 & 36.70 & 14.62 \\
\hline & $\mathrm{F}$ & 379 & 28.70 & 3.94 & 15.63 & 36.70 & 13.72 \\
\hline & $\mathrm{M}$ & 276 & 25.19 & 2.87 & 17.85 & 33.84 & 11.39 \\
\hline
\end{tabular}

Sex: F - Female, M - Male, I - Indeterminate; n: sample size; S.D.: standard deviation; Min: minimum; Max: maximum; and $\mathrm{CV}$ : coefficient of variation (\%). 
Table 2. WLR parameters for 6 shrimp species, Madeira archipelago, northeastern Atlantic.

\begin{tabular}{|c|c|c|c|c|c|c|c|c|c|c|c|}
\hline \multirow{2}{*}{ Family / species } & \multirow{2}{*}{ Sex } & \multirow{2}{*}{$\mathbf{n}$} & \multicolumn{9}{|c|}{ WLR parameters and statistics } \\
\hline & & & $\mathbf{a}$ & SE (a) & $95 \%$ CL (a) & b & SE (b) & $95 \%$ CL (b) & $\mathbf{r}^{2}$ & allometry & $\mathbf{t}$ \\
\hline \multicolumn{12}{|l|}{ Acanthephyridae } \\
\hline \multirow{3}{*}{$\begin{array}{l}\text { Acanthephyra } \\
\text { eximia }\end{array}$} & $\mathrm{F}+\mathrm{M}+\mathrm{I}$ & 388 & 0.053 & 0.047 & $0.048-0.058$ & 2.703 & 0.045 & $2.635-2.771$ & 0.95 & negative & 1.97 \\
\hline & 1 & 249 & 0.052 & 0.057 & $0.046-0.058$ & 2.721 & 0.042 & $2.638-2.803$ & 0.95 & negative & 1.97 \\
\hline & M & 120 & 0.051 & 0.061 & $0.045-0.057$ & 2.721 & 0.045 & $2.633-2.810$ & 0.97 & negative & 1.98 \\
\hline \multicolumn{12}{|l|}{ Hippolytidae } \\
\hline \multirow[t]{3}{*}{ Ligur ensiferus } & $\mathrm{F}+\mathrm{M}+\mathrm{I}$ & 139 & 0.055 & 0.082 & $0.047-0.065$ & 2.791 & 0.063 & $2.666-2.917$ & 0.93 & negative & 1.98 \\
\hline & $\mathrm{F}$ & 72 & 0.057 & 0.126 & $0.044-0.073$ & 2.771 & 0.097 & $2.578-2.963$ & 0.92 & negative & 1.99 \\
\hline & $\mathrm{M}$ & 19 & 0.083 & 0.238 & $0.050-0.137$ & 2.476 & 0.187 & $2.081-2.871$ & 0.91 & negative & 2.10 \\
\hline \multicolumn{12}{|l|}{ Pandalidae } \\
\hline \multirow{3}{*}{$\begin{array}{l}\text { Heterocarpus } \\
\text { laevigatus }\end{array}$} & $\mathrm{F}+\mathrm{M}+\mathrm{I}$ & 221 & 0.046 & 0.071 & $0.040-0.053$ & 2.801 & 0.043 & $2.715-2.886$ & 0.95 & negative & 1.97 \\
\hline & $\mathrm{F}$ & 143 & 0.063 & 0.109 & $0.051-0.080$ & 2.609 & 0.065 & $2.480-2.738$ & 0.92 & negative & 1.98 \\
\hline & $\mathrm{M}$ & 74 & 0.040 & 0.085 & $0.034-0.048$ & 2.876 & 0.053 & $2.769-2.982$ & 0.98 & negative & 2.34 \\
\hline \multirow[t]{3}{*}{ Plesionika ensis } & $\mathrm{F}+\mathrm{M}+\mathrm{I}$ & 81 & 0.053 & 0.094 & $0.044-0.064$ & 2.818 & 0.073 & $2.672-2.964$ & 0.95 & negative & 1.99 \\
\hline & $\mathrm{F}$ & 40 & 0.064 & 0.145 & $0.045-0.081$ & 2.724 & 0.112 & $2.496-2.951$ & 0.94 & negative & 2.02 \\
\hline & M & 15 & 0.098 & 0.141 & $0.072-0.133$ & 2.360 & 0.110 & $2.120-2.599$ & 0.97 & negative & 2.14 \\
\hline \multirow{3}{*}{$\begin{array}{l}\text { Plesionika } \\
\text { martia }\end{array}$} & $\mathrm{F}+\mathrm{M}+\mathrm{I}$ & 51 & 0.059 & 0.118 & $0.046-0.074$ & 2.728 & 0.091 & $2.546-2.910$ & 0.95 & negative & 2.01 \\
\hline & 1 & 24 & 0.071 & 0.204 & 0.047-0.109 & 2.590 & 0.155 & $2.268-2.910$ & 0.93 & negative & 2.07 \\
\hline & M & 22 & 0.068 & 0.146 & $0.050-0.093$ & 2.598 & 0.113 & $2.361-2.834$ & 0.96 & negative & 2.08 \\
\hline \multirow{3}{*}{$\begin{array}{l}\text { Plesionika } \\
\text { williamsi }\end{array}$} & $\mathrm{F}+\mathrm{M}+\mathrm{I}$ & 677 & 0.071 & 0.056 & $0.064-0.080$ & 2.592 & 0.040 & $2.514-2.671$ & 0.94 & negative & 1.96 \\
\hline & $\mathrm{F}$ & 379 & 0.046 & 0.062 & $0.041-0.05$ & 2.915 & 0.042 & $2.831-2.998$ & 0.95 & negative & 1.97 \\
\hline & M & 276 & 0.057 & 0.059 & $0.052-0.066$ & 2.703 & 0.043 & 2.619-2.786 & 0.92 & negative & 1.97 \\
\hline
\end{tabular}

Sex: F - Female, M - Male, I - Indeterminate; $\mathrm{n}$ : sample size, $\mathrm{a}$ and $\mathrm{b}=$ parameters of equation $\mathrm{W}=\mathrm{aL}^{\mathrm{b}}$; S.E.: standard error; CL 95\%: confidence limits; $r^{2}$ : coefficient of determination, type of allometry; and t: test values.

Aristeus antennatus (Risso, 1816) (Carbonell et al., 1999) and Heterocarpus laevigatus (Dailey and Ralston, 1986).

This pattern results in higher mobility thus providing an advantage in predation in highly specialized active predators of macroplanktonic species as stated by Cartes (1993). The negative allometric nature of growth in the studied species might also be related to the low availability of preys in oligotrophic waters as previously reported for P. martia by Thessalou-Legaki et al. (2005) in the Eastern Ionian Sea.

In crustaceans, food availability and water temperature play an important role in growth dynamics. In habitats with more available food and higher temperatures, crustaceans tend to have higher growth rates (Hartnoll, 1983). The differences in the values of the $b$ parameter between the study species probably results of differences in feeding and breeding behavior and greater capacity of obtaining, converting and storing energy according to depth.

When considering differences according to sex, in the parameter $\mathrm{b}$ for $A$. eximia, L. ensiferus, P. martia and $P$. williamsi no statistically significant differences were found, which is in accordance with previous results obtained by Thessalou-Legaki et al. (2005), even tough for P. ensis and $H$. laevigatus there were statistically significant differences in the relative growth coefficient, these did not alter the negative allometric nature of growth for these species, such fluctuations in relative growth might be related to differences in reproductive activity and habitat preference between sexes in P. ensis and H. laevigatus.

This study provides significant amount of information on weight length relationships of shrimp species in the Northeastern Atlantic, being the first parameter estimates for these six species from the Madeira archipelago and in the cases of $L$. ensiferus and $P$. ensis the first references worldwide, thus providing useful information to be used in future studies dealing with the commercial fisheries of these shrimps.

\section{Acknowledgements}

The authors are grateful to the Fisheries Research Service (DSI) from the Regional Directorate of Fisheries of the Autonomous Region of Madeira for providing the data used in this study. We are also grateful to the technicians of DSI for their help in the course of this work, namely in biological sampling and fishing surveys. Financial support was granted by the UE FEDER in the framework of the Project MARISCOMAC - MAC/2.3d/097 and the Regional Government of Madeira. The first author (RS) 
was supported by a Grant from ARDITI-OOM/2016/010 (M1420-01-0145-FEDER-000001-Observatório Oceânico da Madeira-OOM).

\section{References}

ANDERSON, R. and GUTREUTER, S., 1983. Length, weight and associated structural indices. In: L. NIELSON and D. JOHNSON, eds. Fisheries techniques. Maryland: American Fisheries Society, pp. 283-300.

ANDREU-SOLER, A., OLIVA-PATERNA, F.J. and TORRALVA, M., 2006. A review of length-weight relationships of fish from the Segura River basin (SE Iberian Peninsula). Journal of Applied Ichthyology, vol. 22, no. 4, pp. 295-296. http://dx.doi. org/10.1111/j.1439-0426.2006.00719.x.

BAGENAL, T.B. and TESCH, F.W., 1978. Age and growth. In: T. BAGENAL, ed. Methods for assessment of fish production in fresh waters. Oxford: Blackwell Scientific Publications, chapt. 5, pp. 101-136.

BISCOITO, M.J., 1993. An account of the shrimps of the family Pandalidae (Crustacea, Decapoda, Caridea) in Madeiran waters. Courier Forschunginstitut Senckenberg, vol. 159, pp. 321-325.

BISCOITO, M.J., PINTO, A.R., MAUL, G.E., FARIA, G.T. and AMORIM, A.B., 1992. Estudo ecológico e biológico das comunidades de peixes e crustáceos decápodes bentónicos da vertente continental da Madeira. Funchal: MMF and DSIP, pp. 1-59. Relatório de Progresso do Projecto PMCT/C/Mar/985/90.

CARBOnell, A., CARBOnEll, M., DEMESTRE, M., GRAU, A. and MONSERRAT, S., 1999. The red shrimp Aristeus antennatus (Risso, 1816) fishery and biology in the Balearic Islands, western Mediterranean. Fisheries Research, vol. 44, no. 1, pp. 1-13. http://dx.doi.org/10.1016/S0165-7836(99)00079-X.

CARLANDER, K.D., 1969. Handbook of freshwater fishery biology. Ames: Fishing News Books, vol. 1.

CARLANDER, K.D., 1977. Handbook of freshwater fishery biology. Ames: The Iowa State University Press, vol. 2.

CARTES, J.E., 1993. Diets of deep-water pandalid shrimps on the western Mediterranean slope. Marine Ecology Progress Series, vol. 96, pp. 49-61. http://dx.doi.org/10.3354/meps096049.

COMPANY, J.B. and SARDÀ, F., 2000. Growth parameters of deep-water decapod crustaceans in the northwestern Mediterranean Sea: a comparative approach. Marine Biology, vol. 136, no. 1, pp. 79-90. http://dx.doi.org/10.1007/s002270050011.

DAILEY, M.D. and RALSTON, S., 1986. Aspects of reproductive biology. spatial distribution. growth and mortality of the deep water caridean shrimp Heterocarpus laevigatus, in Hawaii. Fish Bulletin, vol. 84, pp. 915-925.

ERZINI, K., 1994. An empirical study of variability in length-at-age of marine fishes. Journal of Applied Ichthyology, vol. 10, no. 1, pp. 17-41. http://dx.doi.org/10.1111/j.1439-0426.1994.tb00140.x.

FERREIRA, S., SOUSA, R., DELGADO, J., CARVALHO, D. and CHADA, T., 2008. Weight-length relationships for demersal fish species caught off the Madeira archipelago (eastern-central Atlantic). Journal of Applied Ichthyology, vol. 24, no. 1, pp. 93-95. http://dx.doi.org/10.1111/j.1439-0426.2007.01027.x.

FROESE, R., 2006. Cube law, condition factor and weight-length relationships: history, meta-analysis and recommendations. Journal of Applied Ichthyology, vol. 22, no. 4, pp. 241-253. http://dx.doi. org/10.1111/j.1439-0426.2006.00805.x.

GONZÁLEZ, J.A., PAJUELO, J.G., TRIAY-PORTELLA, R., RUIZ-DÍAZ, R., DELGADO, J., GÓIS, A.R. and MARTINS, A., 2016. Latitudinal patterns in the life-history traits of three isolated Atlantic populations of the deep-watershrimp Plesionika edwardsii (Decapoda, Pandalidae). Deep-sea Research. Part I, Oceanographic Research Papers, vol. 117, pp. 28-38. http:// dx.doi.org/10.1016/j.dsr.2016.09.004.

GONZÁLEZ, J.A., TUSET, V.M., LOZANO, I.J. and SANTANA, J.I., 1997. Biology of Plesionika narval (Crustacea, Decapoda, Pandalidae) around the Canary Islands (eastern central Atlantic). Estuarine and Coastal Marine Science Journal, vol. 44, no. 3, pp. 339-350. http://dx.doi.org/10.1006/ecss.1996.0122.

HARTNOLL, R.G., 1983. Growth. In: B.E. BLISS, ed. The biology of crustacea. New York: Academic Press, vol. 8, pp. 214-282.

KING, M., 1995. Fisheries biology, assessment and management. Oxford: Fishing News Books.

MAIORANO, P., D’ONGHIA, G., CAPEZZUTO, F. and SION, L., 2002. Life-history traits of Plesionika martia (Milne Edwards, 1883) (Decapoda: Caridea) from the eastern-central Mediterranean Sea. Marine Biology, vol. 141, no. 3, pp. 527-539. http://dx.doi.org/10.1007/s00227-002-0851-4.

MARTINS, H. and HARGREAVES, P., 1991. Shrimps of the Families Pandalidae and Hippolytidae (Crustacea: Decapoda) caught in benthic traps off the Azores. Arquipélago Life Earth Science, vol. 9, pp. 47-61.

PÉREZ-PEÑALVO, J.A., GONZÁLEZ, J.A., PINHO, M.R., TUSET, V.M., DELGADO, J., BISCOITO, M., CARVALHO, D. and SANTANA, J.I., 2009. Biology of the deep-water shrimp Heterocarpus ensifer (Caridea: Pandalidae) off the Canary, Madeira and the Azores islands (Northeastern Atlantic). Journal of Crustacean Biology, vol. 29, no. 4, pp. 507-515. http://dx.doi. org/10.1651/08-3070.1.

RAGONESE, S., BERTOLINO, F. and BIANCHINI, M.L., 1997. Biometric relationships of the red shrimp, Aristaeomorpha foliacea Risso 1827, in the Strait of Sicily (Mediterranean Sea). Scientia Marina, vol. 61, no. 3, pp. 367-377.

ROCHET, M.J., 2000. May life history traits be used as indices of population viability? Journal of Sea Research, vol. 44, no. 1-2, pp. 145-157. http://dx.doi.org/10.1016/S1385-1101(00)00041-1.

SANTOS, M.N., GASPAR, M.B., VASCONCELOS, P. and MONTEIRO, C.C., 2002. Weight-length relationships for 50 selected fish species of the of the Algarve coast (southern Portugal). Fisheries Research, vol. 59, no. 1-2, pp. 289-295. http://dx.doi. org/10.1016/S0165-7836(01)00401-5.

SOUSA, R., HENRIQUES, P., BISCOITO, M., PINTO, A.R., DELGADO, J., DELLINGER, T., GOUVEIA, L. and PINHO, M.R., 2014. Considerations on the Biology of Plesionika narval (Fabricius, 1787) in the Northeastern Atlantic. Turkish Journal of Fisheries and Aquatic Sciences, vol. 14, pp. 727-737. http:// dx.doi.org/10.4194/1303-2712-v14_3_15.

SOUSA, R., PINHO, M.R., DELGADO, J., BISCOITO, M., PINTO, A.R., DELLINGER, T., GOUVEIA, L., CARVALHO, D. and HENRIQUES, P., 2016. Prospective study of the fishery of the shrimp Plesionika narval (Fabricius, 1787) in the Northeastern Atlantic. Brazilian Journal of Biology $=$ Revista Brasileira de Biologia, vol. 77, no. 3, pp. 585-593. http://dx.doi. org/10.1590/1519-6984.21015. PMid:27783766. 
THESSALOU-LEGAKI, M., PETRAKIS, G. and CHILARI, A., 2005. Population structure and reproduction of the deep-water shrimp Plesionika martia (Decapoda: Pandalidae) from the eastern Ionian Sea. Journal of Crustacean Biology, vol. 25, no. 2, pp. 233-241. http://dx.doi.org/10.1651/C-2513.

VAFIDIS, D., LEONTARAKIS, P.K., DAILIANIS, T. and KALLIANIOTIS, A., 2008. Population characteristics of four deep-water pandalid shrimps (Decapoda: Caridea) in the northern Aegean Sea (NE Mediterranean). Journal of Natural History, vol. 42, no. 31-32, pp. 2079-2093. http://dx.doi. org/10.1080/00222930802254672.

ZAR, J.H., 1996. Biostatistical analysis. New Jersey: PrenticeHall International Editions.

ZARIQUIEY-ALVAREZ, R., 1968. Crustáceos decápodos ibéricos. Investigaciones Pesqueras, vol. 32, pp. 1-510. 